\title{
Choice Constructions of Indonesian Muslimah in Purchasing Halal Cosmetics
}

\author{
${ }^{1}$ Rishan Adha, ${ }^{2}$ Selva \\ 1,2Universitas Muhammadiyah Mataram, Mataram, Indonesia \\ 1ishanadha@gmail.com, ${ }^{2}$ selva@gmail.com
}

\begin{tabular}{|c|c|}
\hline Article Info & Abstract \\
\hline $\begin{array}{l}\text { Article History } \\
\text { Received: July 12, } 2018 \\
\text { Accepted: September 30, } \\
2018\end{array}$ & \multirow{2}{*}{$\begin{array}{l}\text { Cosmetic choice for Muslimah is not as simple as we think because it relates } \\
\text { to the looks, aesthetics, exposures, and hopes. This study aimed to determine } \\
\text { the construction of Muslimah choice in the purchase of cosmetics. The study } \\
\text { was conducted by using direct experiments to Muslimah. The experiments } \\
\text { were conducted in a controlled environment, where the female respondents } \\
\text { were divided into nine groups, with three levels of income and three levels of } \\
\text { knowledge about halal cosmetics. This procedure results in more accurate } \\
\text { measurements because the variables are controlled by the researchers. The } \\
\text { results indicate that there is difference of consumer choice construction } \\
\text { between knowledge level and income level. The variable of knowledge level } \\
\text { gives a better influence in purchasing decision of halal cosmetics product } \\
\text { compared with variable of income level. Different treatments in the provision } \\
\text { of halal product information tend to influence consumer purchasing } \\
\text { decisions with lower income levels compared with high income consumers. }\end{array}$} \\
\hline $\begin{array}{l}\text { Keywords } \\
\text { Behavior, Income, Cognition, } \\
\text { Halal Product }\end{array}$ & \\
\hline $\begin{array}{l}\text { Support by: } \\
\text { dol Crossref }\end{array}$ & \\
\hline
\end{tabular}

\section{INTRODUCTION}

Halal lifestyle is currently a trend in various parts of the world. In general, halal lifestyle is defined as the use of halal products in accordance with Islamic Shariah in everyday life. The development of halal lifestyle can be seen from several phenomena such as the increase of societal awareness in assessing halal products to consume, the development of Shariah-based financial institutions, the growth of Islamic cultures, the development of the use of hijab, the emergence of Sharia hotels, increased frequency of visits and pilgrimage, the growth of the halal cosmetics industry and the rise of Muslim entrepreneurship.

For Muslims, consuming halal products today is not just a liability but has shifted into a lifestyle. In the Muslim majority, the concept of halal is an absolute key to consumption. Muslim consumers nowadays are faced with a broad selection of products and services. Each product category offers many assorted brands either locally named or internationally recognized. Some of the local brands appear by themselves as "Islamic" brands via their creative packaging and labeling. This also indirectly signals to their primary target, which is the Muslim consumer, the halal status of their products. Halal is also one of the five actions (Al-Ahkam al- Khamsah) which became the basis for the determination of moral actions of human action in Islam, consisting of fard (obligatory), mustahab (recommended), makruh (disliked), and haram (prohibition). Halal and haram are not only related to consumption activities but also related to all human activities such as trading activities that must be clean of elements of usury and cheating. The religiosity factor in Indonesian society also cannot be ignored because the factor of religiosity will affect the behavior of a person to spend his income. 
Halal aspects of a product also cannot be separated from the concept of thoyyib. If halal refers to the law of whether or not a product is consumed, then thoyyib put more emphasis on quality aspects of products such as nutritional content, hygiene and product safety, health, affordability and other benefits. The concept of can also be regarded as the superiority of competitiveness for halal products.

One of the industries that became the barometer of halal products is cosmetics. The cosmetics industry is one of the largest industries in the world, including in Indonesia. Until 2013, the world wide annual expenditures for cosmetics is estimated at U.S. \$ 18 billion, and the companies in the field are competing aggressively to capture more and more market. According to Euromonitor, the cosmetics and toiletries are divided into nine categories, deodorants, hair care, color cosmetics, men's grooming products, oral hygiene, fragrances, skin care, depilatories and sun care. The beauty and cosmetics sector are experiencing outstanding growth. It has been one of the world's leading industries. The cosmetics industry also has a long history, since Cleopatra from Alexandria used cosmetics derived from various plants and earth minerals, to the new cosmetics from Kyle Jenner who became the women dreams of the world.

Halal cosmetic products, though unlike halal food or beverage products strictly selected by Muslim consumers, remain an important standard especially in Muslimmajority countries. Increased halal awareness in Indonesian society has a major impact on every industry, including the cosmetics industry. So, now we find many halal cosmetics products even some halal cosmetics brands have gained a large market share in Indonesia. From the data taken from the LPPOM MUI up to 2018, cosmetics that have received halal certificate from MUI reached 162 products.

However, the cosmetic industry is a unique industry because it relates to the looks, aesthetics, exposures, and hopes. Moreover, lofty expectations in the use of cosmetics often make consumers marginalize aspects of cognition, especially related to product knowledge. This causes in most cases, consumers often do not pay attention to the halal aspect of cosmetic products when compared with processed foods or beverage products. This is very reasonable considering the food is a basic human need, in addition to consumer awareness of halal non-food products are also still low. Not surprisingly, 3 of the 10 most popular cosmetics brands in Indonesia (bitebrands.co version) still do not have halal certificate from MUI..

\section{METHOD}

The method in this research is experimental research. The experimental method is used because the researcher wants to know the construction of consumer choice by tightly controlling the consumer choice variable. Experimental methods in economics have been largely concerned with economic behavior [14]. All experimental subjects were divided into nine groups showing three different levels of knowledge about halal cosmetic products that showed aspects of consumer cognition and three different levels of income to show perceptions of consumer behavior control:

\begin{tabular}{|l|l|l|}
\hline Group 1 & Group 4 & Group 7 \\
X1.1/X2.1 & X1.2/X2.1 & X1.3/X2.1 \\
\hline Group 2 & Group 5 & Group 8 \\
X1.1/X2.2 & X1.2/X2.2 & X1.3/X2.2 \\
\hline Group 3 & Group 6 & Group 9 \\
X1.1/X2.3 & X1.2/X2.3 & X1.3/X2.3 \\
\hline
\end{tabular}

Notes:

Figure 1: Group design and Independent Variable

$\mathrm{X} 1$ = Level of Cognition 

X1.1 = Without Product Information
$\mathrm{X} 1.2$ = halal Product Information without discussion
$\mathrm{X} 1.3$ = halal Product Information with discussion
$\mathrm{X} 2$ = Level of Income
$\mathrm{X} 2.1=$ Low Income
$\mathrm{X} 2.2$ = Middle Income
$\mathrm{X} 2.3$ = High Income

Each group gets the same treatment in the experiment to know the construction of consumer choice. In the experiment, each group is given a selection of cosmetic packages that should be spent using the revenue earned. Cosmetic package offered is divided into 3 different cosmetic package, where package $A$ is cosmetics that do not have halal label, packet B is cosmetics which already have halal label but the strength of weak halal brand, packet $C$ is cosmetic which already have halal label and strong halal brand, as shown in the table below:

\begin{tabular}{|l|l|l|}
\hline Package A & Package B & Package C \\
\hline Rev*** Bob*** $_{\text {Bro } * * \text { Ana } * * * * * *}$ & Sar**** & War*** Maz*** \\
& Pur******Viv* & Zoy* Cos****** \\
\hline
\end{tabular}

Table 1: Cosmetics Packages

The experiment was conducted in Mataram City with 180 Muslimahs who were university students in Mataram? The use of female students in the research allows researchers in controlling other variables outside the study. Experimental tests were conducted at the University of Muhammadiyah Mataram on 2 - 12 May 2018.

\section{RESULT}

Experiments in this study used the subject of students in the city of Mataram who came from several universities both public universities and private universities. The total respondents used in Islamic experiments with the age range

19-23 years. The use of female college respondents is not uncommon because the young female segment is usually the main target market for cosmetics producers. At that age level, consumer awareness to appear more attractive tends to be higher because it is driven from social interaction more than other age level, but at that age level generally the financial condition of consumers is still not established so that the sensitivity to the price is quite high.

The experimental results based on the proposed hypothesis are summarized in the table below.

\begin{tabular}{|c|c|c|c|c|c|}
\hline Source & $\begin{array}{c}\text { Type I Sum } \\
\text { of Square }\end{array}$ & df Square & Mean & $\mathrm{F}$ & $p$-value Square \\
\hline Model & $998.750 \mathrm{a}$ & 9 & 110.972 & 205.705 & $0.000^{* *}$ \\
\hline Cognition & 992.817 & 3 & 330.939 & 613.448 & $0.000^{* *}$ \\
\hline Income & 5.078 & 2 & 2.539 & 4.706 & $0.010^{* *}$ \\
\hline Interaction & 0.856 & 4 & 0.214 & 0.396 & 0.811 \\
\hline
\end{tabular}

Table 2: Hypotheses Testing

Notes: Significance at: ${ }^{* *} \alpha<0.01 ; \mathrm{R} 2=0.915$

From the table above shows that the coefficients of significance for hypothesis 1 (combined), Hypothesis 2 (Cognitive Effect), and Hypothesis 3 (Income Effects) are all smaller than the $5 \%$ or 0.05 alpha level and have F count $>\mathrm{F}$ table. As for the fourth hypothesis (interaction between cognition and income) shows that the coefficient 
significance greater than alpha $5 \%$ or 0.05 and has the $\mathrm{F}$ count $<\mathrm{F}$ table. Thus it can be concluded that:

Hypothesis 1:

The proposed of hypothesis 1 can be accepted or in other words there is a difference construction of consumer choice to the halal product between the level of product knowledge and inter-income level simultaneously. Hypothesis 2:

The proposed of hypothesis 2 can be accepted or in other words there is a difference construction of consumer choice between knowledge level of halal product.

Hypothesis 3:

The proposed of hypothesis 3 can be accepted or in other words there are differences in consumer choice constructs between income levels. Hypothesis 4:

The proposed of hypothesis 4 is rejected or in other words there is no significant interaction between product knowledge and consumer income level.

From the above table can also be seen variables of cognition or consumer knowledge is better than the variable income level in influencing the construction of consumer choice for the purchase of kosher cosmetics products. It can be seen from the mean square and p-value values owned by the cognition variable are better than the income level variable. In other words, cognition variables are better able to influence consumer purchasing decisions in buying kosher cosmetics products.

After performing the test of significance in general, further testing of significance was conducted for each pair. Research requires testing the differences per pair to determine which pairs differ significantly and which pairs are no different. To do the analysis used multiple comparisons for each independent variable.

From the calculation results note that some pairs on cognition variables are significantly different. Couples without knowledge and video without discussion have a mean difference of -0.5500 and a p-value of 0.000 . In addition, the couples without knowledge and video with discussion have a mean difference of -0.7333 and $p$-value of 0.000 . For income level variables, there is only one significant different pair of low income and high income couples, having a mean difference of 0.4000 and p-value 0.009 . It shows that simulated cognition factor with giving video and discussion between experiment subjects can influence the decision of halal cosmetic product purchase seen from the real difference between pre and post treatment after product information. The model of information sharing used in this

study is also divided into two, namely the giving of video without discussion and giving video with discussion. The video that was screened before the purchase of cosmetics by consumers is a video about the production process of halal cosmetics as well as messages about the importance of the use of halal products in everyday life. In addition, it also moral persuasion appeals related to the use of halal products not only halal food or beverages but also halal cosmetics.

Different treatment for each group is possible in experimental research to see the interrelations between each treatment different from the results obtained. In various experimental studies related to economics and business, the results obtained can also be used as input for the company or economic institution in need, because experimental research using the human subject as the core of the experiment so often called the study of economic behavior. 


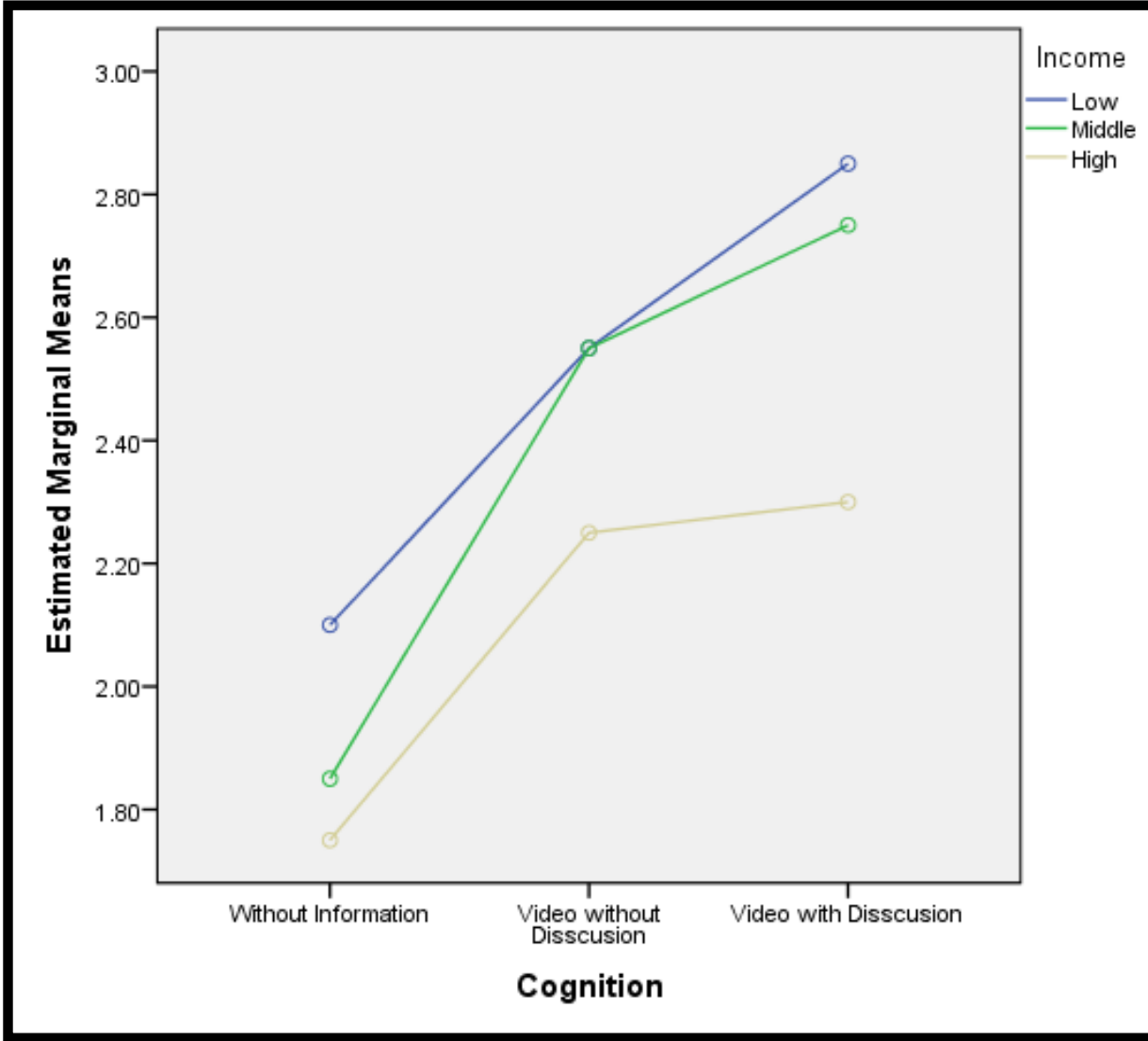

Figure 2: Estimated Marginal Means of Purchasing

From the plots above, it can be seen that there is a real difference construction of consumer choice without being given information by providing information about halal products. Providing information with video but without being given discussion opportunities and interacting with other experimental subjects can still increase the consumer's tendency to buy kosher cosmetic products, at all income levels. Information sharing and discussion opportunities further increase the consumer's tendency, especially simulated consumers who have low income levels, to buy kosher cosmetic products. While at a higher income level, the tendency of consumers to spend their income on halal cosmetics products is declining.

This phenomenon is not surprising because some previous studies have shown that the choice of kosher cosmetic products is not like the choice of halal food or beverage that is more noticed by Muslim consumers. The degree of religiosity possessed by experimental subjects is not a factor studied by researchers but may be an input to previous studies because in some cases, the factor of religiosity also influences the consumer's choice of halal products. The study also confirms that human behavior is linked to product purchases, not only to the market environment but also to the social environment, since consuming halal products is closely related to personal awareness and social pressure from the surrounding environment.

\section{CONCLUTION}

The results showed that the construction of consumer choice (Muslimah) to the purchase of halal cosmetics products varies depending on the level of knowledge about product information and the level of consumer income. Differences in the treatment of the provision of information about halal products will result the better tendency of consumers in the selection of halal cosmetics products. A better level of knowledge 
about halal cosmetics products will increase the trend of halal cosmetics purchases, especially in simulated consumers who have low income levels. While at a higher income level the consumer's tendency to spend his income on halal cosmetics products is lower than consumers with lower income levels.

\section{REFERENCE}

[1] E. D. Tarigan. (2016). "Pengaruh Gaya Hidup, Label halal dan Harga Terhadap Keputusan Pembelian Kosmetik Wardah pada Mahasiswa Program Studi Manajemen Fakultas Ekonomi Universitas Medan," J. Konsep Bisnis dan Manaj., vol. 3, no. 1, pp. 47-61.

[2] S. S. Alam and N. M. Sayuti. (2011). "Applying the Theory of Planned Behavior ( TPB ) in halal food purchasing," Int. J. Commer. Manag., vol. 21, no. 1, pp. 8-20.

[3] M. Battour and M. N. Ismail. (2015). "Halal tourism : Concepts , practices, challenges and future," TMP, pp. 8-12.

[4] N. H. Endah. (2014). "Perilaku Pembelian Kosmetik Berlabel Halal oleh Konsumen Indonesia," J. Ekon. dan Pembang., vol. 22, no. 1, pp. 11-25.

[5] D. Yener. (2014). "The Effect of Religiosity on Product Involvement in a Muslim Society," J. Bus. Res., vol. 6, no. 1, pp. 58-69.

[6] V. Jawahar and K. Tamizhjyothi. (2013). "Consumer Attitude Towards Cosmetic Products," IJEMR, vol. 3, no. 6, pp. 1-7.

[7] A. A. Khalek, S. Hayaati, and S. Ismail. (2015). "Why Are We Eating halal - Using the Theory of Planned Behavior in Predicting halal Food Consumption among Generation Y in Malaysia," Int. J. Soc. Sci. Humanit., vol. 5, no. 7, pp. 608-612.

[8] A. Jihan, M. Hashim, and R. Musa. (2014). "Factors Influencing Attitude Towards halal Cosmetic Among Young Adult Urban Muslim Women : A Focus Group Analysis," Procedia - Soc. Behav. Sci., vol. 130, pp. 129-134.

[9] M. H. Kamali. (2003). Principles of Islamic Jurisprudence, Third Edit. Islamic Text Society.

[10] S. Lada, G. H. Tanakinjal, and H. Amin. (2009). "Predicting intention to choose halal products using theory of reasoned action," Int. J. Islam. Middle East. Financ. Manag., vol. 2, no. 1, pp. 66-76.

[11] S. Mokhlis. (2008). "Consumer Religiosity and the Importance of Store Attributes," vol. 4, no. December, pp. 122-133.

[12] I. Ajzen. (1991). "The Theory of Planned Behavior," Organ. Behav. Hum. Decis. Process., vol. 50, pp. 179-211. 